\title{
Study on the Multinational Project Procurement and Tax Planning
}

\author{
Gang Wan
}

Xinxing Cathay Resources Development Co.,Ltd., Beijing, 101100

Keywords: multinational project; procurement planning; tax planning

\begin{abstract}
Since China implemented reform and opening-up, enterprises and the economy have made long-term progress after more than 30 years of development. In recent years, the development of the world economy has shown the characteristics and trend of globalization, and multinational corporations have also been established. In order to adapt to the development of the times, domestic companies in China have begun to conduct business and expand the development space worldwide. However, the journey to success overseas is not smooth. While implementing the internationalization strategy of the economy to the world, Chinese enterprises are also faced with various risks brought by them, including political, financial, legal, cultural, taxation and operational risks. Among them, the T company implements a transnational business strategy, so it will face the differences in tax laws and regulations and collection and management regulations. Through the investigation of the financial management practices implemented by Chinese enterprises in the past few decades, it is found that the concept of tax management in China is far from foreign countries. Therefore, it is necessary to strengthen the management of overseas tax risks. For enterprises, they must also pay attention to the importance of tax management. Otherwise, they will not be able to adapt to the development of overseas strategies, and they will not be able to effectively control risks. In the face of fierce international competition, they will not take advantage and will bring losses to the company.
\end{abstract}

\section{Introduction}

The overseas contracted project is mainly based on the entrusted relationship. It is the project contractor who carries out the design, construction, machinery, equipment, raw materials, technical personnel, supervision and other specific work for a certain engineering task according to the relevant agreement: The project called "turnkey" or project contracting is comprehensive and international, and belongs to an international labor cooperation P1. Since the implementation of China's reform and opening up, all walks of life have achieved long-term development, overseas contracting: Cheng's business is also included, and with further advancement, achieved rapid growth and development. For the time being, after more than 20 years of development, it has played an increasingly important role in China's foreign trade economy, both in terms of the total volume of the foreign trade economy and the development of China's national economy. The role. In the basic policy of implementing reform and opening up in China, it is proposed to "go global", and all foreign contracted enterprises actively respond to this policy and have achieved rapid development and achievements. With the further development of foreign contracted projects, it has continuously transformed and expanded in terms of business growth and scale, and has further expanded in the field of development, reflecting the characteristics of diversification. In recent years, attention has been paid to mine construction to ensure the stability and sustainability of its development.

\section{Tax Planning for Business Activities of Multinational Companies}

Tax relief can also be called a virtual or agave credit, mainly for the government of the country of residence. If the tax amount that the resident should bear in foreign countries has been reduced or exempted according to relevant regulations, it is deemed to have been paid and should not be In accordance with the country's laws on taxation, tax rates, etc., it is required to make up the payment. The taxation is special, in order to achieve the cooperation of the credit method, with additionality, 
mainly based on Ding? The basis of the credit method and the implementation of an economic policy are a kind of preferential tax. The preferential treatment is usually determined based on the content of the bilateral tax treaty. For the time being, when making tax credits, it is mainly carried out by means of balance and rate.

Direct credit means that when taxation is imposed on corporate taxpayers, the taxable amount of the enterprise should be deducted from the portion already paid abroad. Direct credit has a certain scope of application, mainly because the business operating profit is derived from overseas and has been paid overseas. In addition, it includes income tax, interest, property transfer, dividends, rents, etc. that have been withdrawn or deducted from overseas through sources. The indirect credit for the main game is for foreign companies, the process of paying the foreign income tax before the distribution of dividends, the part of the indirect burden of the Chinese resident enterprises, the tax payable in China The dividend burden in the middle is offset. For example, a resident company in China has set up a corresponding subsidiary abroad, and the subsidiary has paid the corresponding corporate income tax in the country where it is located, and distributed a portion of the profit after tax to a company as a dividend dividend, which the company paid abroad. Among the tax amount of corporate income tax, the proportion of the after-tax profit distributed to the parent company is the part of the parent company that needs to pay the income tax and the indirect burden to the overseas enterprise.

Transfer pricing is generally limited. It refers to large enterprise groups. Multinational companies are also included. By comparing the differences between different companies, tax rates, and tax exemptions, if there is a lower tax rate in the location of the branch. Or, in the case of tax exemption, the transfer of profits to the branch is realized. Specifically, the group of companies has different pricing at different tax rates and presents a negative correlation.

Tax haven refers to the preferential treatment of investors in a country or region for the purpose of attracting foreign investment, prospering economy or introducing advanced foreign technology, and giving investors no tax or less tax in certain areas of their own country or country. Generally speaking, tax havens often have conditions such as no tax or relatively low tax rate, stable currency, flexible exchange system, full use of tax treaties, political stability, and convenient transportation. Through investigations of multinational corporations, it can be found that, for the time being, most of the internationally controlled insurance companies will be established in the corresponding tax havens, including two main reasons;

(1) Most of the tax havens are not levied or the company's income is levied at a very low rate. There are also many tax incentives. (2) Accumulating most of the profits in the tax haven to realize the delay in the payment of corporate income tax; (3) These tax havens usually do not impose withholding tax, which is convenient for enterprises to distribute profits as dividends. An offshore company is a company that conducts related business activities outside the scope based on the place of registration. Worldwide, there are many offshore financial centers, including the Cayman Islands, Bermuda, Samoa, the British Virgin Islands, the Bahamas, etc., which are mainly through the law in the process of economic activities. The use of the environment to achieve economic development in the region is relatively loose, international people can set up corresponding international business companies within this scope. These areas can be referred to as offshore jurisdictions. Offshore companies are generally a generic term referring to companies incorporated in the region that are incorporated under the Offshore Companies Act and that do not operate within the scope of the registration. The meaning of "offshore" is that the main purpose is to start the registration. The investor registers the relevant company in the offshore jurisdiction, but does not have to operate in the area, and can carry out corresponding business transactions around the world. For example, you can register a trading company in the Bahamas, but you can do business in Europe and the Americas.

\section{Recommendations for Tax Planning of Multinational Project}

Establish the idea of attaching importance to tax planning. The responsible attitude of seeking truth from facts and obeying the law is the basis of tax planning. Some basic methods and 
viewpoints are similar when planning taxation, but there are big differences in the behavior of each country, project, and economic activity. Serious research and research on the country's taxation financial system is needed. Otherwise, it may be a boastful castle in the air, not operational, or risking the law of the country. In many countries, if companies are found to be dishonest because of tax evasion, it means being permanently expelled from the country's market. When we engage in economic activities in the host country, we are obliged to pay taxes according to law. How to avoid overpayment of taxes, or repeated payment in multiple countries is the focus of tax planning. In Western countries, it is common for professional financial experts to conduct research on the taxation legal system of the investing country, and to carry out corresponding tax planning to avoid heavier tax burdens, and set up special posts. Once the policy was formulated, it was well implemented and implemented as the core policy of the company.

The taxation problem is combined with engineering process reengineering. The implementation of international engineering projects and domestic construction processes vary widely, and the internationally recognized methods of design, construction, measurement and supervision of the entire project are implemented. There is also a big difference in the way in which metering and engineering fees are paid. For example, a very common phenomenon in the Algeria East-West Expressway is that each time the metering payment progress payment is made, the engineering contractor must attach the current tax payment certificate, otherwise it will not be paid. Therefore, in the tax arrangement, the degree of each measurement payment should be combined with the one-year tax payment in the country or the whole project settlement. Otherwise, the tax after each payment is difficult to offset and rush back at the end of the project. . Reasonable arrangements for procurement, progress, etc. during construction. After the project's tax-saving plan is formulated, the tax-saving income is reasonably reflected in the measurement payment of each period. A high degree of confidentiality should be maintained for the tax-saving measures. Any enterprise's tax strategy is highly confidential and should not be spread over a large area. In the executive layer, the relevant practices of other parts of this layer should not be known. That is to say, accurate implementation, and establish a corresponding firewall system and separate documents to separate the custody system. The role of financial personnel in tax planning. The more the economy develops, the more important accounting is. The "business language" provided by accountants can accurately reflect the taxpayer's financial status, operating results and cash flow, provide a basis for investors' decision-making, and create conditions for tax planning. The tax planning of international engineering projects is also mainly formulated, implemented and revised by the project manager and the corresponding project financial experience. The financial personnel should formulate plans for the project and the fiscal and taxation environment of the host country. It is necessary to select the planning entry point from the tax-related matters and tax-related links. It is necessary to fully understand the project financing plan, project investment and production and operation planning plan, and combine the host country's various Regulatory provisions will be tax planning

Consider it in the overall business decision. It also needs to be recognized by the tax authorities and intermediaries, and can make a well-founded explanation of the issues raised by the tax authorities and safeguard the legitimate rights and interests of the project contractor.

\section{Conclusion}

International engineering tax planning is still relatively lacking for Chinese companies, and implementation is even more difficult. It is extremely important for project managers to arrange the smooth implementation of the project and maximize the benefits of the contractor. Good construction procurement plans and arrangements can save the contractor tens of millions of dollars in taxes and fees. Definitely worthy of our every manager to study and think. Strengthening knowledge learning in international tax planning, understanding international taxation knowledge, studying the tax environment of host countries, and drawing on international popular practices have considerable guiding significance for tax planning of engineering contractors in China. 


\section{References}

[1] Han Lin. Tax Management Strategy for Chinese Enterprises to Go Global: Interview with Dr. Zhan Qingrong, a Multinational Tax Management Expert [J]. Foreign Taxation, 2008 (12).

[2] Yuan Yongfeng. Tax planning for general contracting business at home and abroad [J]. Modern Business, 2008(12)

[3] Teng Lin. Tax planning for going out - Interview with Mr. Huang Fucheng, Partner of PricewaterhouseCoopers [J]. New Finance, 2008 (12).

[4] Jiang Wei. Thoughts on International Tax Avoidance Planning Methods and Their Applications [J]. Finance and Accounting Learning, 2008 (10). 